\title{
Öğretmen Adaylarının Başarılarının Değerlendirilmesinde Tercih Ettikleri Ölçme Araçlarının Belirlenmesi
}

\section{Determining the Pre-Service Teachers' Measurement Tool Preferences for Evaluation of their Achievement}

\author{
Melek Gülşah ŞAHIIN* Nagihan BOZTUNÇ ÖZTÜRK ${ }^{* *}$ Gülşen TAŞDELEN TEKER ****
}

\section{$\ddot{O} \mathbf{z}$}

$\mathrm{Bu}$ araştırmanın amacı, öğretmen adaylarının değerlendirilme tercihlerinin sıralama yargılarına dayalı olarak ölçeklendirilmesi yöntemiyle belirlenmesidir. Çalışmada veri toplama aracı olarak, eğitim fakültesi öğrencilerinin başarılarının değerlendirilmesinde tercih ettikleri ölçme araçlarını belirlemeye yönelik geliştirilen araç kullanılmıştır. Bu araç ile öğretmen adaylarının sekiz tane ölçme aracına ilişkin tercihlerini belirtmeleri istenmiştir. Araştırmaya, 2010-2011 öğretim yılı güz döneminde Hacettepe Üniversitesi Eğitim Fakültesi'nin beş farklı bölümünde öğrenim gören 163 öğrenci katılmıştır. Araştırma sonuçlarına göre öğretmen adaylarının en çok doğru-yanlış testlerini, en az ise performans görevlerini tercih ettikleri belirlenmiştir. Sonuçlar daha detaylı incelendiğinde ise geleneksel yaklaşımların tamamlayıcı yaklaşımlara göre daha üst sıralarda tercih edildiği bulgusuna ulaşılmışıtır.

Anahtar Kelimeler: değerlendirme tercihleri, ölçme araçları, ölçekleme, sıralama yargıları yöntemi

\begin{abstract}
The aim of this study is to determine the measurement tool preferences of pre-service teachers for the evaluation of their achievement via sorting judgments scaling method. In the study, an instrument was developed and used to collect data about the education faculty students' assessment preferences. By using this instrument, pre-service teachers were asked to state their assessment preferences among the eight measurement tools given to them. The sample of the study was 163 pre-service students from five different departments of Faculty of Education of Hacettepe University in 2010-2011 academic year. According to the results of the study, it was concluded that the true-false test were the most preferred tools; on the other hand, performance tasks were the least preferred ones. When the results of the study examined deeply, it was found that the classical measurement tools were preferred more than the alternative tools.
\end{abstract}

Key Words: assessment preferences, measurement tools, scaling, rank order judgment scaling method

\section{GíRIŞ}

Eğitim ve öğretimin istenilen düzeye ulaşıp ulaşmadığının belirlenmesi ölçme ve değerlendirme ile mümkün olmaktadır. Tüm eğitim kademelerinde öğretmenler ölçme sonuçlarından yola çıkarak öğrencilere ilişskin çeşitli kararlar vermektedir. Verilen kararların isabet derecesi seçilen değerlendirme yönteminin uygunluğu ile de ilişkilidir. Öğrencilerin çalışma alışkanlıkları, öğrenme yaklaşımları, ne düzeyde öğrendikleri, ne öğrendikleri, bilgiyi kullanma ve uygulamaya dönüştürme becerileri gibi pek çok değişken, seçilen

\footnotetext{
* Okutman Dr., Gazi Üniversitesi, Gazi Eğitim Fakültesi, Ankara-Türkiye, mgulsah@gazi.edu.tr

** Eğitim ve Öğretim Planlamacısı Dr., Hacettepe Üniversitesi, ÖİDB-İzleme ve Değerlendirme Birimi, Ankara-Türkiye, nagihanboztunc@ hacettepe.edu.tr

*** Öğretim Görevlisi Dr., Sakarya Üniversitesi, Hendek Eğitim Fakültesi, Sakarya-Türkiye, gtasdelen@sakarya.edu.tr
} 
değerlendirme yöntemine bağlı olarak farklılık göstermektedir (Gülbahar ve Büyüköztürk, 2008).

Öğrencilerin eğitim ve öğretim hayatında büyük bir öneme sahip ölçme ve değerlendirmenin başarılı bir şekilde uygulanmasında en büyük görev öğretmenlere düşmektedir. Öğretmenlerin ölçme ve değerlendirme alanındaki yeterliliklerine ilişkin ön bilgileri öncelikle lisans eğitiminde Ölçme ve Değerlendirme dersinde kazanmaları hedeflenmektedir. Öğretmen yetiştiren kurumlarda yer alan Ölçme ve Değerlendirme dersinin içeriği, YÖK (2008) tarafından "Eğitimde ölçme ve değerlendirmenin yeri ve önemi, ölçme ve değerlendirme ile ilgili temel kavramlar, ölçme araçlarında bulunması istenen nitelikler (güvenirlik, geçerlik, kullanışl1lık), eğitimde kullanılan ölçme araçları ve özellikleri, geleneksel yaklaşımlara dayalı olan araçlar (yazılı sınavlar, kısa yanıtlı sınavlar, doğru-yanlış tipi testler, çoktan seçmeli testler, eşleştirmeli testler, sözlü yoklamalar, ödevler), öğrenciyi çok yönlü tanımaya dönük araçlar (gözlem, görüşme, performans değerlendirme, öğrenci ürün dosyası, araştırma kâğıtları, araştırma projeleri, akran değerlendirme, öz değerlendirme, tutum ölçekleri), ölçme sonuçları üzerinde yapılan temel istatistiksel işlemler, öğrenme çıktılarını değerlendirme, not verme, alanı ile ilgili ölçme aracı geliştirme" olarak tanımlanmıştır. Buradan da anlaşıldığı üzere, 2005 yılında MEB tarafından yapılandırmacı eğitim anlayışının benimsenmesiyle eğitim programlarında ve ölçme ve değerlendirme yaklaşımlarında yapılan değişiklikler YÖK'ün ders içeriğine de yansıtılmıştır. $\mathrm{Bu}$ bağlamda ölçme araçlarına genel olarak bakıldığında geleneksel ve yapılandırmacı ölçme ve değerlendirme yaklaşımlarının temel alındığı geleneksel ve tamamlayıcı araçlar olarak ikiye ayrıldığı ifade edilebilir.

Geleneksel ölçme araçlarında öğrenci başarısının değerlendirilmesi öğretim sürecinden ayrı ve daha çok ürüne ağırlık verecek şekilde ele alınmaktadır. Bu amaçla çoktan seçmeli, kısa cevaplı testler, yazılı ve sözlü yoklamalar kullanılmaktadır. Yapılandırmacı öğrenme yaklaşımının temel alındığı tamamlayıcı öğrenme yaklaşımında ise değerlendirme öğretim sürecinde gerçekleşmekte ve bu amaçla geleneksel araçlara ek olarak öğrenci başarısının sınıf dışı değerlendirilmeleri, ilgi ve tutumlarının belirlenmelerini de ele alınarak öğrenci performansının geniş bir değerlendirilmesi söz konusu olmaktadır (Gelbal ve Kelecioğlu, 2007). Öğrenci performanslarının çeşitli yönleri ile değerlendirilmesinin söz konusu olması nedeniyle tamamlayıcı ölçme araçları bize öğrenci hakkında daha zengin bir bilgi sunmaktadır. Ayrıca Duban ve Küçükyılmaz (2008)'a göre; tamamlayıcı ölçme ve değerlendirme yaklaşımlarının öğrencinin düzeyine uygun ve yaşamla ilişkili olması gereğinden dolayı ögrenciye "anlamlı ve ilginç" gelen değerlendirme stratejilerini de içermektedir (Şad ve Göktaş, 2013).

Geleneksel ölçme değerlendirme anlayışında bireylerin bilgi ya da becerilerine göre sınıflandırılmaları hedeflenirken, tamamlayıcı ölçme ve değerlendirme teknikleri ile öğrencinin öğrenme sürecinin neresinde olduğu da belirlenmektedir (Şad ve Göktaş, 2013; Gömleksiz ve Kan, 2010; Şenel Çoruhlu, Er Nas ve Çepni, 2009). Öğrencinin bilişsel, duyuşsal ve devinimsel gelişiminin önemli olduğu göz önüne alındığında tamamlayıcı ölçme araçlarının öğrenci gelişiminin öğretimin bir parçası olarak izlenmesine olanak sağladığı ifade edilebilir. Yapılandırmacı yaklaşımın temele alındığı ölçme ve değerlendirme 
yaklaşımında geleneksel yaklaşıma kıyasla daha çok ve çeşitli araçların kullanılmasını gerektirmektedir (İzci, Göktaş ve Şad, 2014; Özenç, 2013; Acar ve Anıl, 2009; Duban ve Küçükyılmaz, 2008; Gelbal ve Kelecioğlu, 2007).

Alanyazında tamamlayıcı ölçme ve değerlendirme yaklaşımlarına ilişkin çalışmalar söz konusudur (İzci, Göktaş ve Şad, 2014; Şaşmaz Ören, Ormanc1 ve Evrekli, 2014; Gömleksiz ve Kan, 2010; Buldur, 2009; Çoklar, Vural ve Şahin, 2009; Duban ve Küçükyılmaz, 2008; Gijbels ve Dochy, 2006). Bu çalışmaların sonuçları incelendiğinde, Şaşmaz Ören ve diğ. (2014) araştırmalarında, öğretmen adaylarının tamamlayıcı ölçme ve değerlendirme araçlarını ileride öğretmenlik yaşantılarında sıklıkla kullanmak istediklerini ifade ettikleri belirlenmiştir. Duban ve Küçükyılmaz (2008) ise öğretmen adaylarının tamamlayıcı ölçme araçlarının kullanımına olumlu yaklaştıklarını ayrıca devam ettikleri uygulama okullarında ise en çok performans görevi ve proje uygulamalarının tercih edildiğini belirtmiş olduğunu araştırmalarında vurgulamışlardır.

Ayrıca alanyazında hem geleneksel hem de tamamlayıcı ölçme ve değerlendirme yaklaşımlarının incelendiği çalışmalarda söz konusudur (Altun ve Gelbal, 2014; Şad ve Göktaş, 2013; Tuncer ve Y1lmaz, 2012; Bay ve diğ, 2010; Birgün ve Gürbüz, 2008; Gelbal ve Kelecioğlu, 2007; Struyven, Dochy ve Janssens, 2005). Altun ve Gelbal (2014) öğretmenlerin kullandıkları ölçme ve değerlendirme yöntem veya araçlarının ikili karşılaştırma yöntemiyle ölçekleyerek belirlemeye çalışmışlardır. Araştırmada ilköğretim öğretmenlerinden, belirlenen sekiz yöntemi ikili karşılaştırma yoluyla değerlendirmeleri istenmiştir. Araştırmada öğretmenlerin en çok performans değerlendirmeyi en az ise günlük tutma yöntemini tercih ettikleri belirlenmiştir.

Tuncer ve Yılmaz (2012) öğretmenlerin kullandıkları ölçme ve değerlendirme yaklaşımlarını kıdem değişkeni açısından ele almışlardır. Araştırmada öğretmenlerin ölçme araçları kullanımında bilgi eksiklikleri olduğu ve öğretmenlerin önemli bir kısmının geleneksel ölçme ve değerlendirme yaklaşımlarını kullanmaya devam ettikleri belirlenmiştir. Şad ve Göktaş (2009) öğretim elemanlarının ölçme ve değerlendirme yaklaşımlarını ne düzeyde benimsediklerini belirlemeye çalışmışlardır. Araştırma sonuçlarına göre, öğretim elemanlarının hem geleneksel hem de tamamlayıcı ölçme ve değerlendirme yaklaşımlarını orta düzeyde benimsedikleri ancak tamamlayıcı yaklaşımlara ait ortalamaların nispeten daha yüksek elde edildiği ortaya konmuştur. Gelbal ve Kelecioğlu (2007) öğretmenlerin ölçme ve değerlendirme yöntemleri hakkındaki yeterlik algılarını ve karşılaştıklaştıkları sorunları belirledikleri çalışmalarında, öğretmenlerin öğrenci başarısını belirlemede kendilerini yeterli ve çoğunlukla geleneksel ölçme yöntemlerini tercih ettiklerini ortaya koymuşlardır.

Öğretmen adaylarının değerlendirilme tercihlerini belirtirken öğrenci olarak göz önünde bulunduracakları bir takım değişkenler de söz konusu olabilir. Alanyazında öğrencilerin değerlendirilme algılarının değişkenlere göre incelendiği çalışmalarda söz konusudur (Struyven, Dochy ve Janssens, 2005; Gijbels ve Dochy, 2006). Struyven, Dochy ve Janssens (2005) yükseköğretimdeki öğrencilerin değerlendirme algıları üzerine bir çalışma yürütmüşlerdir. Bu çalışmada, öğrencilerin nasıl öğrendikleri ve ders çalıştıklarını, kullanılan değerlendirme yönteminin yanı sıra öğrencilerin değerlendirme yöntemlerine ilişkin algılarının da önemli bir şekilde etkilediği vurgulanmıştır. Buna karşın, öğrencilerin ders çalışma yaklaşımlarının da değerlendirme isteklerini etkilediği sonucuna ulaşılmıştır. Gijbels ve Dochy (2006) çalışmalarında uygulamalı (hands-on) deneyimlerin süreç değerlendirmesi, öğrencilerin değerlendirme tercihleri ve öğrenme yaklaşımları arasındaki 
ilişkiyi incelemişlerdir. Çalışmada, ezbere dayalı öğrenme yaklaşımını benimseyen öğrencilerin basit değerlendirme yöntemlerini tercih ettikleri diğer taraftan daha derin öğrenmeler gerçekleştiren öğrencilerin daha karmaşık değerlendirme yöntemlerini tercih ettikleri sonucuna ulaşılmıştır. Bir diğer ifadeyle, öğrencilerin değerlendirme tercihlerinin öğrenme yaklaşımlarındaki farklılıkları ile ilişkili olduğu sonucuna varılmıştır.

\section{Araştırmanın Amact ve Önemi}

Mezun olduktan sonra öğrencilerin değerlendirilmesinden sorumlu olacak öğretmen adaylarının, tamamlayıcı ve geleneksel ölçme ve değerlendirme yaklaşımlarına ilişkin bilgi sahibi olması ve görüsş geliştirmesi beklenmektedir. Öğretmen adaylarının lisans eğitimi sürecinde kendi başarılarının belirlenmesinde değerlendirilme tercihlerinin ne olduğu ise merak uyandırmaktadır. Bu nedenle, bu çalışma ile öğretmen adaylarının değerlendirilme tercihlerinin sıralama yargılarıyla ölçekleme yöntemi ile belirlenmesi amaçlanmıştır.

Öğretmen adaylarının ölçme ve değerlendirme dersi kapsamında, ölçme araçlarının özellikleri, avantaj ve sınırlılıkları ile kullanımlarına ilişkin bilgi edindikleri kabul edilmektedir. Öğretmen adaylarının edindikleri bu bilgiler bağlamında; sınıf içi uygulamalarından önce kendi değerlendirilme tercihlerinin belirlenmesi araştırmanın önemini oluşturmaktadır.

\section{YÖNTEM}

\section{Araştırmanın türü}

Araştırmada var olan yöntem ve tekniklerin gerçek veri üzerinden sınanması yapıldığından betimsel araştırma türündedir (Büyüköztürk, Çakmak, Akgün, Karadeniz ve Demirel, 2008).

\section{Çalışma Grubu}

Araştırmaya 2010-2011 öğretim y1lı güz döneminde Hacettepe Üniversitesi Eğitim Fakültesi Sınıf Öğretmenliği, Fen Bilgisi Öğretmenliği, Fizik Öğretmenliği, Kimya Öğretmenliği ile Bilgisayar Öğretimi ve Teknolojileri Öğretmenliği bölümlerinde öğrenim görmekte olan 163 öğretmen adayı katılmıştır. Bu bölümlerde okuyan öğretmen adaylarının seçilmesinde "Eğitimde Ölçme ve Değerlendirme" dersini almış olmanın dişında özel bir neden bulunmamaktadır. Çalışmayı yürüten araştırmacıların bu bölümlerde öğrenim gören öğretmen adaylarına ulaşabilme kolaylığından ötürü çalışma grubu belirtilen dört bölümde öğrenim görmekte olan öğrencilerden oluşturulmuştur. Araştırmaya katılan 45 öğretmen adayının uygulanan ölçme aracını eksik veya hatalı yanıtladığı görülmüştür. Sonuç olarak, analizler 118 öğrencinin ölçme aracına verdiği yanıtlar üzerinden yapılmıştır.

\section{Veri Toplama Aracının Hazırlanması}

Araştırmada kullanılan ölçme aracı hazırlanırken Milli Eğitim Bakanlığı tarafından 2005-2006 öğretim y1lı itibari ile ilköğretim 1-5 ve kademeli olarak 2006-2007 öğretim yılından itibaren diğer sınıflar için hazırlanan yeni öğretim programlarında yer alan ve çeşitli araştırmalara konu olmuş ölçme araçlarından, en çok kullanılan ve üzerinde araştırma yapılan sekiz tanesi seçilmiştir. Araştırma konusu olan ölçme araçları aşağıdaki gibidir:
A. Çoktan seçmeli sınav
B. Doğru-yanlış sınavı
C. Grup halinde sunum
D. Kisa-cevapli sinav
E. Öğrenci gelişim dosyası (portfolyo)
F. Performans görevi
G. Proje 
H. Yazılı sınav

Veri toplama aracı, seçilen sekiz ölçme aracı ile değerlendirme tercihlerini sıralama yapabilecekleri biçimde düzenlenmiştir. Öğretmen adaylarından bu sekiz ölçme aracını ele alarak dersteki başarıları belirlenirken, en çok kullanılmasını istedikleri ölçme aracına 1 ve en az kullanılmasını istedikleri ölçme aracına 8 sıra numarasını verecek şekilde 1'den 8'e kadar sıra numarası atamaları istenmiştir. Hazırlanan veri toplama aracı, ölçme ve değerlendirme alanında doktora eğitimine sahip iki kişiden uzman görüşü alınmıştır. Ölçme aracındaki ifadeler ve araştırma kapsamında seçilen ölçme araçlarının uygunluğu konusunda yapılan geri bildirimler doğrultusunda gerekli düzeltmeler yapılarak ölçme aracı kullanıma hazır hale getirilmiştir (Ek-1)

\section{Verilerin Analizi}

Öğretmen adaylarının değerlendirme tercihlerinin belirlenmesinde sıralama yargılarıyla ölçekleme yöntemi kullanılmıştır. Bu yöntemde; uyarıcılara belirli bir nitelikte büyükten küçüğe ya da küçükten büyüğe doğru sıralanarak her birine sıradaki yerine göre bir sıra sayısı verilmektedir. Pek çok alanda uygulama yeri bulunan sıralama yargılarıyla ölçekleme yöntemi, gözlemciyi uyarıcılar arasında mümkün olan en büyük sayıda ayırımı yapmaya zorladığından, gözlemcinin bu ayırımı yapabildiği hallerde geçerliği çok yüksek ölçek değerleri verir. Ayrıca bu yöntem kullanılarak elde edilen veriler, orijini ve birimi olmayan, yalnız sıralanan uyarıcılar grubunda anlamlı ölçümlerdir.

Sıralama, sıralanan uyarıcılar arasındaki büyüklük-küçüklük ilişkilerini de belirlediğinden bir başka ölçekleme yöntemi olan ikili karşılaştırmalar yöntemi ile ölçeklemeye çok benzemektedir. Çakışmalara izin verilmeyen bir sıralamanın verileri ikili karşılaştırma yargılarının frekanslarına dönüştürülebilir. Verilerin bu yakın benzerliği yanında, sıralama ile ikili karşılaştırmalarla ölçekleme yöntemleri arasında önemli ayrılıklar da vardır. Sıralama yargılarıyla ölçekleme işleminde uyarıcılar, gözlemcilere ikişer ikişer değil hepsi birden verilir. $\mathrm{Bu}$ da gözlemciye yüklenen iş bakımından sıralamayı ikili karşılaştırmalardan daha pratik bir yöntem haline getirir. Ayrıca, ikili karşılaştırmalarla ölçekleme yönteminde tutarsız üçlüler halinde görülen iç tutarsızlık sıralamada yoktur. $\mathrm{Bu}$ tür tutarsızlıklar hiç değilse suni olarak önlenmiştir (Turgut ve Baykul, 1992).

Verilerin analizinde Microsoft Office Excel programı yardımıyla ölçme araçlarının hangi sıraya kaç kez konulduğunu gösteren sıra frekansları matrisi oluşturulmuştur. Ardından, oranlar matrisi elde edilmiştir. Oranlar matrisinin elemanlarına karşılık gelen z değerleri belirlenerek birim normal sapmalar matrisi oluşturulmuş ve bu matrisin en alt satırına her bir sütuna ait değerlerin toplamı alınarak her bir z değerinin sütunlar boyunca ortalamaları hesaplanarak ölçek değerleri elde edilmiştir.

\section{BULGULAR}

$\mathrm{Bu}$ araştırmada, eğitim fakültesinde öğrenim gören öğretmen adaylarının "değerlendirilme tercihleri" sıralama yargıları yöntemi ile ölçeklendirilmiştir. Yürütülen ölçekleme çalışmasında yer alan aşamalar tablolar ile birlikte verilerek açıklanmıştır.

Öğretmen adaylarından, başarılarının değerlendirilmesinde tercih ettikleri ölçme araçlarını en çok (1) tercih ettiklerinden, en az (8) tercih ettiklerine doğru sıralamaları istenmiştir. Elde edilen veriler kullanılarak, öncelikle Tablo 1' de verilen sıra frekansları matrisi oluşturulmuştur. $\mathrm{Bu}$ matrisin satır ve sütunlarının toplamı toplam kişi sayısını vermektedir $(\mathrm{N}=118)$. 
Tablo 1. Sira Frekanslarl (F) Matrisi

\begin{tabular}{cccccccccc}
\hline \multirow{2}{*}{$\mathrm{R}_{\mathrm{ij}}$} & $\mathrm{r}_{\mathrm{ij}}$ & \multicolumn{10}{c}{ Uyarıc1ar } \\
\cline { 3 - 10 } & & $\mathrm{A}$ & $\mathrm{B}$ & $\mathrm{C}$ & $\mathrm{D}$ & $\mathrm{E}$ & $\mathrm{F}$ & $\mathrm{G}$ & $\mathrm{H}$ \\
\hline 1 & 8 & 14 & 11 & 4 & 19 & 21 & 11 & 8 & 30 \\
2 & 7 & 7 & 32 & 25 & 12 & 9 & 16 & 12 & 5 \\
3 & 6 & 25 & 24 & 18 & 10 & 10 & 13 & 7 & 11 \\
4 & 5 & 36 & 10 & 16 & 12 & 10 & 6 & 15 & 13 \\
5 & 4 & 5 & 8 & 20 & 14 & 13 & 17 & 32 & 9 \\
6 & 3 & 4 & 10 & 17 & 30 & 19 & 18 & 8 & 12 \\
7 & 2 & 9 & 13 & 11 & 7 & 11 & 20 & 16 & 31 \\
8 & 1 & 18 & 10 & 7 & 14 & 25 & 17 & 20 & 7 \\
\hline
\end{tabular}

Tablo 1'de yer alan sıra frekans değerlerinden $n\left(S_{j i}>S_{k i}\right)=f_{j i .}\left(f_{k<i}+1 / 2 f_{k i}\right)$ eşitliğ yardımıyla her bir uyarı için ayrı ayrı hesaplanan $\mathrm{n}\left(\mathrm{s}_{j i}>\mathrm{s}_{k i}\right)$ frekansları elde edilmiştir. Elde edilen frekanslar, Tablo 2 'de verilen frekanslar matrisinde toplanmıştır.

Tablo 2. Frekanslar Matrisi

\begin{tabular}{cccccccc}
\hline & $\mathrm{A}$ & $\mathrm{B}$ & $\mathrm{C}$ & $\mathrm{D}$ & $\mathrm{E}$ & $\mathrm{F}$ & $\mathrm{G}$ \\
\hline $\mathrm{A}$ & & & & & & & \\
$\mathrm{B}$ & 5888,5 & & & & & & \\
$\mathrm{C}$ & 7046 & 7861,5 & & & & & \\
$\mathrm{D}$ & 7367,5 & 7981,5 & 9701,5 & & & & \\
$\mathrm{E}$ & 7619,5 & 8219 & 7743,5 & 7298 & & & \\
$\mathrm{~F}$ & 7825 & 8447,5 & 7995 & 7528,5 & 6845 & & \\
$\mathrm{G}$ & 8404,5 & 8912,5 & 8281 & 7597 & 6958 & 6947,5 & \\
$\mathrm{H}$ & 6987 & 7552,5 & 7799 & 6784,5 & 6154,5 & 6070 & 5831 \\
\hline
\end{tabular}

Tablo 2'de verilen frekanslar matrisinde yer alan her bir hücrenin $\left(\mathrm{f}_{\mathrm{ij}}\right)$ toplam kişi sayısının karesine $\left(\mathrm{N}^{2}=118^{2}\right)$ bölünmesi ile Tablo 3'te yer alan oranlar matrisi $(\mathrm{P})$ elde edilmiştir.

Tablo 3. Oranlar Matrisi

\begin{tabular}{cccccccc}
\hline & $\mathrm{A}$ & $\mathrm{B}$ & $\mathrm{C}$ & $\mathrm{D}$ & $\mathrm{E}$ & $\mathrm{F}$ & $\mathrm{G}$ \\
\hline $\mathrm{A}$ & & & & & & & \\
$\mathrm{B}$ & 0,423 & & & & & & \\
$\mathrm{C}$ & 0,506 & 0,565 & & & & & \\
$\mathrm{D}$ & 0,529 & 0,573 & 0,697 & & & & \\
$\mathrm{E}$ & 0,547 & 0,590 & 0,556 & 0,524 & & & \\
$\mathrm{~F}$ & 0,562 & 0,607 & 0,574 & 0,541 & 0,492 & & \\
$\mathrm{G}$ & 0,604 & 0,640 & 0,595 & 0,546 & 0,500 & 0,499 & \\
$\mathrm{H}$ & 0,502 & 0,542 & 0,560 & 0,487 & 0,442 & 0,436 & 0,419 \\
\hline
\end{tabular}

Oranlar matrisinde yer alan her bir hücrenin oran değerine $\left(\mathrm{p}_{\mathrm{ij}}\right)$ karş1lık gelen $\mathrm{Z}$ standart değeri belirlenerek Tablo 4'te yer alan birim normal sapmalar matrisi (Z) elde edilmiştir. Birim normal sapmalar matrisinde esas köşegene simetrik olan her bir 
hücrede yer alan değerler birbirlerinin ters işaretlisi olup, mutlak değerce birbirlerine eşittir. $Z$ matrisinde her bir sütunda yer alan uyarıcıların ortalamaları alınarak $\left(\Sigma Z_{\mathrm{ij}} / 7\right)$ ölçek değerleri $\left(S_{\mathrm{j}}\right)$ elde edilmiştir.

Tablo 4. Birim Normal Sapmalar Matrisi

\begin{tabular}{ccccccccc}
\hline & $\mathrm{A}$ & $\mathrm{B}$ & $\mathrm{C}$ & $\mathrm{D}$ & $\mathrm{E}$ & $\mathrm{F}$ & $\mathrm{G}$ & $\mathrm{H}$ \\
\hline $\mathrm{A}$ & & 0,194 & $-0,015$ & $-0,073$ & $-0,119$ & $-0,156$ & $-0,263$ & $-0,005$ \\
$\mathrm{~B}$ & $-0,194$ & & $-0,163$ & $-0,185$ & $-0,228$ & $-0,271$ & $-0,359$ & $-0,107$ \\
$\mathrm{C}$ & 0,015 & 0,163 & & $-0,515$ & $-0,141$ & $-0,187$ & $-0,240$ & $-0,151$ \\
$\mathrm{D}$ & 0,073 & 0,185 & 0,515 & & $-0,061$ & $-0,102$ & $-0,115$ & 0,032 \\
$\mathrm{E}$ & 0,119 & 0,228 & 0,141 & 0,061 & & 0,021 & 0,001 & 0,146 \\
$\mathrm{~F}$ & 0,156 & 0,271 & 0,187 & 0,102 & $-0,021$ & & 0,003 & 0,161 \\
$\mathrm{G}$ & 0,263 & 0,359 & 0,240 & 0,115 & $-0,001$ & $-0,003$ & & 0,205 \\
$\mathrm{H}$ & 0,005 & 0,107 & 0,151 & $-0,032$ & $-0,146$ & $-0,161$ & $-0,205$ & \\
$\mathrm{~S}_{\mathrm{j}}\left(\sum \mathrm{Zij} / 7\right)$ & 0,062 & 0,215 & 0,151 & $-0,075$ & $-0,102$ & $-0,123$ & $-0,168$ & 0,040 \\
\hline
\end{tabular}

Bir sonraki aşamada, eksenin başlangıç noktasını $\mathrm{S}_{\mathrm{j}}$ satırındaki en küçük değer olan -0,168 değerine kaydırmak için her bir ölçek değerine bu değerin mutlak değeri olan 0,168 değeri eklenip $S_{c}$ ölçek değerleri elde edilmiştir. Tablo 5 'te ölçme araçları ve her bir ölçme aracına ait $S_{j}, S_{c}$ ve sıra numaraları verilmiştir.

Tablo 5. Ölçme Araçları ve Ölçek Değerleri

\begin{tabular}{lccc}
\hline Ölçme Araçları & $\mathrm{S}_{\mathrm{j}}$ & $\mathrm{S}_{\mathrm{c}}$ & Sıra No \\
\hline A. Çoktan Seçmeli Testler & 0,062 & 0,230 & 3 \\
B. Doğru-Yanlış Testleri & 0,215 & 0,383 & 1 \\
C. Grup Halinde Sunumlar & 0,151 & 0,319 & 2 \\
D. Kısa Cevaplı Testler & $-0,075$ & 0,093 & 5 \\
E. Öğrenci Gelişim Dosyası (Portfolyo) & $-0,102$ & 0,066 & 6 \\
F. Proje & $-0,123$ & 0,045 & 7 \\
G. Performans Görevleri & $-0,168$ & 0,000 & 8 \\
H. Yazılı Yoklamalar & 0,040 & 0,208 & 4 \\
\hline
\end{tabular}

$\mathrm{Bu}$ şekilde elde edilen her bir ölçme aracının ölçek değeri Şekil 1'de verilen sayı doğrusu üstünde gösterilmektedir.

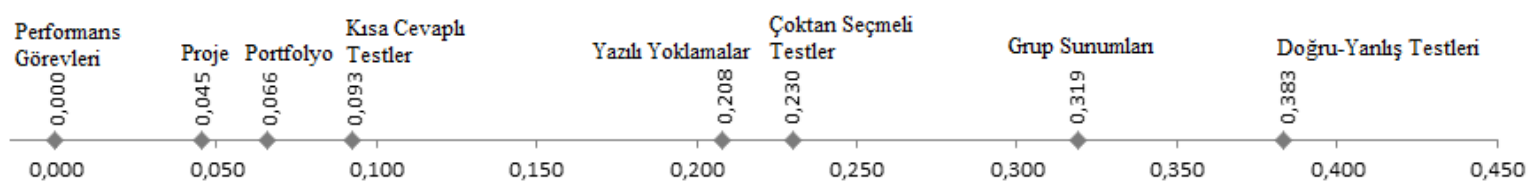

Şekil 1. Ölçme Araçlarının Sıralama Yargıları Yöntemi Sonucunda Ölçekleme Boyutundaki Yerleri

Şekil 1 incelendiğinde; öğretmen adaylarının başarılarının değerlendirilmesinde tercih ettikleri "doğru-yanlış testlerinin' ilk sırada, "performans görevlerinin” ise son sırada yer aldığı görülmektedir. Doğru yanlış testlerini sırasıyla grup halinde sunumlar, çoktan seçmeli testler, yazılı yoklamalar, kısa cevaplı testler, öğrenci gelişim dosyası (portfolyo) ve 
projeler izlemektedir. Yazılı yoklamalar ve çoktan seçmeli testlerin ölçek değerleri ile öğrenci gelişim dosyası (portfolyo), proje ve kısa cevaplı testlerin ölçek değerleri birbirlerine oldukça yakın, yazılı yoklamalar ve kısa cevaplı testlerin ölçek değerleri arasındaki fark ise yüksek çıkmıştır. Buna göre; yazılı yoklamalar ve çoktan seçmeli testler ile öğrenci gelişim dosyası (portfolyo), proje ve kısa cevaplı testler öğrencilerin başarılarının değerlendirilme tercihlerindeki seçimleri açısından birbirlerine benzemektedirler.

\section{TARTIŞMA VE SONUÇ}

$\mathrm{Bu}$ araştırmada, eğitim fakültesinde öğrenim gören öğretmen adaylarının değerlendirilme tercihleri sıralama yargıları ile ölçeklenerek elde edilmiştir. Çalışma sonuçlarına göre eğitim fakültesi öğrencilerinin kendilerine sunulan sekiz ölçme aracından en çok tercih edilen ölçme aracı doğru-yanlış testleri olarak belirlenirken, en az tercih edilen ölçme aracı ise performans görevleri olmuştur.

Yapılan sıralamalar incelendiğinde, geleneksel ölçme araçlarından olan doğru-yanlış testleri, çoktan seçmeli testler, yazılı yoklamalar ve kısa cevaplı testlerin sirasıyla 1, 3, 4 ve 5. sıralarda yer aldığı görülürken tamamlayıcı ölçme araçlarından olan grup halinde sunumlar, portfolyo, proje ve performans görevlerinin ise sirasiyla 2, 6, 7 ve 8 . siralarda yer aldığı sonucuna ulaşılmıştır. Diğer bir ifadeyle, çalışma kapsamında ele alınan ölçme araçlarından geleneksel olarak tanımlanabilecek ölçme araçlarının öğrencilerin değerlendirilme tercihleri içerisinde daha üst sıralarda yer alırken tamamlayıcı ölçme araçlarının sıralamada daha aşağılarda yer almıştır. Bu bulguya paralel olarak, Struyven, Dochy ve Janssens (2005)'in yaptığı araştırmada, öğrencilerin cevabın kendileri tarafından yapılandırılmasına ihtiyaç duyulmayan çoktan seçmeli testler gibi ölçme araçlarının, daha kolay, düşük kaygı ile sonuçlanan ve yüksek başarıya ulaşma beklentisi taşıdıkları için sıklıkla tercih edildiği belirtilmiştir.

Elde edilen ölçek değerleri göz önünde bulundurulduğunda, ölçme araçlarının üç temel grupta toplandığı sonucu gözlenmektedir (Bknz Şekil 1). Buna göre birinci grupta ilk iki sırada yer alan ölçme araçları (doğru yanlış testleri ve grup halinde sunumlar) bulunmakta ve birbirlerine oldukça yakın ölçek değerine sahip oldukları görülmektedir. İkinci grupta, ölçek değeri bakımından üçüncü ve dördüncü sırada yer alan çoktan seçmeli testler ile yazılı yoklamalar bulunmaktadır. Ölçek değerleri ve sıralamada son dörtte yer alan ölçme araçlarının (kısa cevaplı testler, portfolyo, proje ve performans görevi) ölçek değerlerinin ise görece birbirlerine yakın olduğu ve üçüncü grupta yer aldıkları söylenebilir.

İlk ve üçüncü sıralarda yer alan her iki ölçme aracıda belli oranlarda şans başarısı içermektedir. $\mathrm{Bu}$ sebepten dolayı, tercih sıralamasında üst sıralarda yer aldıkları düşünülebilir. Eğitim sistemimizde ulusal çapta yürütülen sınavlarda da seçmeli maddelerin bulunduğu testlerin kullanılması, alışkanlıklardan dolayı bu sonucu doğurmuş olabilir. Özellikle yükseköğretimde öğrencilere yaptırılan sunumların ise bu ölçme aracının eğitim fakültesine okuyan öğretmen adayları tarafından tercih sırasının bu kadar yüksek çıkmasında bir etken olduğu düşünülmektedir.

Eğitimde geleneksel araçların yanı sıra öğrencilerin daha üst düzey becerilerini işe koşabilecekleri fırsatlar tanıyan tamamlayıcı ölçme araçlarının da etkili bir şekilde kullanılması gerekmektedir. Bu çalışma ile elde edilen sonuçlarda, öğretmen adaylarının kendi değerlendirilmelerinde daha çok geleneksel yaklaşımları tercih etmeleri, öğretmen olduklarında kendi öğrencilerini değerlendirirken de bu araçları kullanmaya istekli olacakları şekilde düşünülebilir. Ancak eğitim sisteminde yapılmaya çalışılan değişikliklerle, bireylere kazandırılmaya çalışılan beceriler, geleneksel ve alternatif 
yaklaşımların birlikte kullanılması ile mümkün olacaktır. Bu sebeple, eğitim fakültelerinde verilen Ölçme ve Değerlendirme dersi kapsamında, sadece araçların genel özellikleri değil aynı zamanda bu araçların öğrencilere sağlayacağı faydalar üzerinde de önemle durulmasına da ihtiyaç vardır. Bu bağlamda, eğitim fakültelerinde bu derse giren öğretim elemanlarına büyük görev düşmektedir. Bu sayede öğretmen adayları, mesleğe atıldıklarında, tamamlayıcı araçları kullanmalarının öğrencilerine sağlayacağı faydayı da göz önünde bulundurarak araç tercihinde bulunacaklardır.

Altun ve Gelbal (2014), Öztürk, Hastürk ve Demir (2013), Duran, Mihladız ve Balleel (2013) ile Çepni ve Çoruhlu'nun (2010) öğretmenlerin kullandıkları tamamlayıcı ölçme ve değerlendirme yaklaşımlarına ilişkin yaptıkları çalışmalarda, bu çalışmanın aksine performans görevleri birinci sırada tercih edilmiştir. Öğretmen adaylarının aksine, meslekte görev yapan öğretmenlerin bu tercihlerinin gerekçesi incelendiğinde ise özellikle ilköğretim öğretmenlerinin her iki dönemde de bütün öğrencilere performans değerlendirme notu vermek zorunda olmaları ve dolayısıyla performans değerlendirme yapmak zorunluluğu ile karşılaşılmaktadır. Altun ve Gelbal (2014) çalışmalarında, öğretmenlerin uygulamalar sırasında tamamlayıcı yöntemlerin bir kısmının ne olduklarını bilmediklerini dile getirdiklerini ve açıklama yapılmasını istediklerini ifade etmişlerdir. Bu sonuçlar ışığında, eğitim fakültelerinde öğrenim gören öğretmen adaylarının mezun olmak için zorunlu almaları gereken bir ders olan Ölçme ve Değerlendirme dersinde bu yöntem ve araçların daha detaylı olarak ele alınması gerekliliği ortaya çıkmaktadır. Bu sayede, hem öğretmen adayları bu yöntemlerin avantajlarını daha iyi kavrayarak kendi değerlendirilmelerinde de tercih edebilecek hem de ileride mesleğe atıldıklarında uygun ortam ve şartlar dâhilinde bu yöntemleri zorunlu olmasalar bile gerçekten uygulamaya istekli olacaklardır.

Araştırmadan elde edilen sonuçlar ışığında, şu öneriler sıralanabilir: Bu çalışmada nicel olarak toplanan veriler ile ortaya çıkan sonuçların gerekçelerini detaylandırmak üzere öğretmen adaylarıyla yüz yüze görüşmeler yapılabilir. $\mathrm{Bu}$ araştırmada, ölçekleme yöntemlerinden yalnızca sıralama yargılarıyla ölçekleme yöntemi kullanılmış olup, farklı yöntem ve/veya yöntemler kullanılarak elde edilen sonuçların karşılaştırıldığı çalışmalar yürütülebilir.

Değerlendirme tercihlerinin öğretmen adayına bırakılmasının, öğrenciyi, öğrenmeyi ve başarıyı nasıl etkilediği konusunda çalışmalar yapılabilir. Bunun yanı sıra, öğretmen adaylarının değerlendirilme tercihlerinin cinsiyet, yaş ve öğrenim görülen bölüm gibi çeşitli değişkenlerin de göz önünde bulundurularak karşılaştırıldığı çalışmalar yürütülebilir. Ayrıca öğrencilerin değerlendirilme tercihlerini etkileyen öğrenci ve öğretmene ilişkin değişkenlerin belirlenebileceği çalışmalarda araştırmacılara önerilebilir.

\section{KAYNAKLAR}

Acar, M. ve Anıl, D. (2009). Sınıf öğretmenlerinin performans değerlendirme sürecindeki değerlendirme yöntemlerini kullanabilme yeterlikleri, karşılaştıkları sorunlar ve çözüm önerileri. TUBAV Bilim Dergisi, 2(3), 354-363

Altun, A. ve Gelbal, S. (2014). Öğretmenlerinin kullandıkları ölçme ve değerlendirme yöntem veya araçlarının ikili karşılaştırma yöntemiyle belirlenmesi. Eğitimde ve Psikolojide Ölçme ve Değerlendirme Dergisi, Cilt 5, Say1 1, Yaz 2014, 1-11.

Buldur, S. (2009). Fen bilgisi ögretmen adaylarının alternatif ölçme ve değerlendirme yaklaşımlarına yönelik okuryazarlık ve öz yeterlik düzeylerinin geliştirilmesi. Yayımlanmamış yüksek lisans tezi, Cumhuriyet Üniversitesi, Sivas. 
Büyüköztürk, Ş., Çakmak, E., Akgün, Ö. E., Karadeniz, Ş., ve Demirel, F. (2008). Bilimsel araşttrma yöntemleri. Ankara: Pegem A Yayıncılik.

Çepni, S. ve Çoruhlu, T. Ş. (2010). Alternatif ölçme ve değerlendirme tekniklerine yönelik hazırlanan hizmet içi eğitim kursundan öğretime yansımalar. Pamukkale Üniversitesi Eğitim Fakültesi Dergisi, 28(2), 117 128.

Çoklar, N., Vural, L. ve Şahin, L., (2009). Öğretmen adaylarının uygulayabilecekleri ölçme-değerlendirme yaklaşımları ile ölçme değerlendirme amaçlı teknoloji kullanım öz yeterlikleri. Adıyaman Üniversitesi Sosyal Bilimler Enstitüsü Dergisi, 2(3), 35-54.

Duban, N. ve Küçükyılmaz, E. A. (2008). Sınıf öğretmeni adaylarının alternatif ölçme-değerlendirme yöntem ve tekniklerinin uygulama okullarında kullanımına ilişkin görüşleri. İlköğretim Online, 7(3), 769-784.

Duran, M., Mıhladız, G. ve Ballıel, B. (2013). İlköğretim öğretmenlerinin alternatif değerlendirme yöntemlerine yönelik yeterlik düzeyleri. Mehmet Akif Ersoy Üniversitesi Eğitim Bilimleri Enstitüsü Dergisi, 2(2), 26-37.

Gelbal, S. ve Kelecioğlu, H. (2007). Öğretmenlerin ölçme ve değerlendirme yöntemleri hakkındaki yeterlik algıları ve karşılaş̧ıkları sorunlar. Hacettepe Üniversitesi Eğitim Fakültesi Dergisi, 33, 135-145.

Gijbels, D. ve Dochy, F. (2006). Students' assessment preferences and approaches to learning: can formative assessment make a difference? Educational Studies, 32(4), 399-409.

Gömleksiz, M. N. ve Kan, A. Ü. (2010). Sınıf öğretmeni adaylarının alternatif ölçme-değerlendirme yaklaşımlarını tanıma düzeylerine ilişkin bir değerlendirme. Doğu Anadolu Bölgesi Araştırmaları, 9(1), 2127.

Gülbahar, Ş. ve Büyüköztürk, Ş. (2008). Değerlendirilme tercihleri ölçeğinin Türkçeye uyarlanması. Hacettepe Üniversitesi Ĕgitim Fakültesi Dergisi, 35, 148-161.

İzci, E., Göktaş, Ö. ve Şad, S. N. (2014). Öğretmen adaylarının alternatif ölçme değerlendirmeye ilişkin görüşleri ve yeterlilik algıları. Ahi Evran Üniversitesi Kırşsehir Ĕgitim Fakültesi Dergisi, 15 (2), 37-57.

Özenç, M. (2013). Sınıf öğretmenlerinin alternatif ölçme ve değerlendirme bilgi düzeylerinin belirlenmesi. Dicle Üniversitesi Ziya Gökalp Eğitim Fakültesi Dergisi, 21, 157-178.

Öztürk, N., Yalvaç Hastürk, N.G. ve Demir, R. (2013). İlköğretim 4-5. sınıf fen ve teknoloji dersi öğretim programlarındaki ölçme ve değerlendirme yöntemlerine ilişkin öğretmen görüşleri. Dicle Üniversitesi Ziya Gökalp Ĕ̈itim Fakültesi Dergisi, 20, 25-36.

Struyven, K., Dochy, F. ve Janssens, S. (2005). Students' perceptions about evaluation and assessment in higher education: a review. Assessment and Evaluation in Higher Education, 30(4), 325-341.

Şaşmaz Ören, F.,Ormancı, Ü. ve Evrekli, E. (2014). Öğretmen adaylarının tercih ettikleri alternatif ölçmedeğerlendirme yaklaşımları ile bu yaklaşımlara ilişkin öz-yeterlilikleri. Ĕgitim ve Bilim. 39 (173).

Şad, S. N. ve Göktaş, Ö. (2013). Öğretim elemanlarının geleneksel ve çağdaş ölçme değerlendirme yaklaşımlarının incelenmesi. Ege Ë̆itim Dergisi 14 (2), 79-105.

Tuncer, M. ve Yılmaz, Ö. (2012). Kıdem değişkeni açısından ölçme ve değerlendirme yaklaşımlarının kullanımı üzerine bir araştırma. Ĕgitim ve Öğretim Araşstırmaları Dergisi 1(4), 41-48.

Turgut M.F. ve Baykul, Y. (1992). Ölçekleme teknikleri. Ankara: ÖSYM Yayınları.

YÖK (2008). Ortaöğretim alan öğretmenliği tezsiz yüksek lisans programı. http://www.yok.gov.tr/content/view/23/59/ (Erişim tarihi: 5.04.2010).

\section{EXTENDED ABSTRACT}

\section{Introduction}

To determine the level of education whether it is achieved the desirable level is possible via measurement and evaluation. The teachers from all education levels try to render a decision on students by using the results of measurement and evaluation tools. Whether the decision is wright or wrong is directly related to the appropriateness of the assessment tool.

To apply the measurement and evaluation applications in a successful way the teachers' mission is the most important one. It is aimed to give the main qualifications about measurement and evaluation tools and their applications to teachers at their undergraduate education at education faculties. The content of the Measurement and Evaluation course which is given to pre-service teachers at education faculties is determined by YÖK (2008) and covers both classical and alternative tools which are based on classical and 
constructivist approaches, respectively. In classical measurement and evaluation approach, it is aimed to categorize the students according to their knowledge and ability by comparing them. On the other hand, students' individual differences are the main point in alternative approaches (Şad ve Göktaş, 2013; Gömleksiz ve Kan, 2010; Şenel Çoruhlu, Er Nas ve Çepni, 2009).

In this study, as having the knowledge and sight of classical and alternative measurement and evaluation tools with the help of measurement and evaluation course, the pre-service teachers' assessment preferences were tried to be determined.

\section{Method}

In this study, an instrument was developed and used to collect data about the education faculty students' assessment preferences. There were eight assessment tools which are multiple choice exam, true-false exam, presentation by group, short-answer exam, portfolio, performance task, project and written exam on the instrument. Those tools were selected since both they are on the Turkish Ministry of Education's curriculum, and mostly used and researched tools in the literature. The instrument was constructed to do sorting eight methods by using the rank order judgment scaling method. The sample of the study was 118 pre-service students from five different departments of Faculty of Education of Hacettepe University in 2010-2011 academic year.

According to the answers of the participants, frequencies of each tool were calculated. Frequency matrix was created from these frequencies. After that, the values in each cell were divided into 118 which is the total number of participants to find out the ratio matrix. Then, the $\mathrm{z}$ values that correspond to ratio matrix elements were identified and following that operation the formation of unit normal variance matrix was implemented. Values that belong to each column were added to the bottom line of unit normal variance matrix and the mean of each $\mathrm{z}$ value in this column were calculated through the columns. As a result of these procedures the scale values for the scaling method were obtained.

\section{Results and Discussion}

When reporting the results, the rank of the assessment tools according to sorting judgement was from highest preferred to lowest is true-false exam, presentations of groups, multiple choice test, written exam, short-answer exam, portfolio, project, and performance task. According to the results of the study, it was seen that the mostly preferred assessment tools could be categorized in classical approaches. On the other hand, the least preferred ones were from the category of alternative assessment tools. The reasons of this situation could be examined in future studies. Moreover, the results of the study could be investigated by means of comparison of gender and/or department of participants of the study. The effects of assessment preferences on students' learning and success could also be examined for future studies. 
Ek 1. Veri Toplama Aracı

\section{Değerli Katılımcı}

$\mathrm{Bu}$ araştırma kapsamında; sizlerin başarınızın belirlenmesinde tercih ettiğiniz ölçme araçlarının belirlenmesi amaçlanmaktadır. Aşağıdaki yer alan ölçme araçlarını başarınızın belirlenmesinde en çok kullanılmasını istediğinizden (1 ile gösteriniz), en az istediğinize (8 ile gösteriniz) doğru sıralamanız istenmektedir. Değerli katkılarınız için teşekkür ederiz.

\begin{tabular}{|l|l|}
\hline Ölçme Aracı & Sıra numarası \\
\hline Çoktan Seçmeli Testler & \\
\hline Doğru-Yanlış Testleri & \\
\hline Grup halinde Sunumlar & \\
\hline Kı̈sa Cevaplı Testler & \\
\hline Öğrenci gelişim dosyası (portfolyo) & \\
\hline Proje & \\
\hline Performans Görevleri & \\
\hline Yazılı Yoklamalar & \\
\hline
\end{tabular}

